UDC 613.6.027: 616.1

DOI: 10.21668/health.risk/2016.4.11.eng

\title{
OCCUPATION AND PATHOLOGY OF THE CARDIOVASCULAR SYSTEM: FACTORS THAT MODIFY THE CAUSAL RELATIONS IN EPIDEMIOLOGICAL STUDIES
}

\author{
S.A. Maksimov, G.V. Artamonova \\ Research Institute for Complex Issues of Cardiovascular Diseases, 6 Sosnovyi Blvd., Kemerovo, 650000, \\ Russian Federation
}

In scientific terms, the protection of workers' health is based on evidence of causal links between occupational factors and the onset of illness (or fatal case). The review considers the factors that modify the causal relations between occupational exposures and pathology of the cardiovascular system of workers in epidemiologic studies. Analysis of published data shows strong role of modifying impact of traditional risk factors, and healthy worker effect in shaping of the levels of cardiovascular disease in the working population. This modifying effect needs to be identified and eliminated at the moment of the analysis of the causal relations between occupational exposure and the development of diseases. Some of the most common methodological mistakes are presented on the example of the concrete case studies: ignoring the traditional risk factors for cardiovascular diseases, considering of correlations of occupational experience with the prevalence of diseases as causal, not as associative (due to age), lack of analysis of the possible occupational selection (artificial or spontaneous) of more healthy workers in poor working conditions. The main directions of methodological approaches of formation of the test samples, the results of analytical and statistical processing techniques eliminating the modifying effect were presented. The author's methodical methods that allow identifying and correction of the modifying effect of the healthy worker effect (healthy hire effect and healthy worker survivor effect) on the relative risk and etiologic fraction of disease in occupational groups on the basis of epidemiological data were highlighted in details. It is noted that a broader and more complete use of the modern developed methodological approaches to the formation of the test samples as well as to the results of analytical and statistical processing techniques, can significantly improve the adequacy and reliability of national epidemiological studies.

Key words: cardiovascular disease, occupation, risk factors, healthy worker effect, epidemiological studies, methodical methods, evidence-based medicine.

International healthcare system since 1990 -s is actively introducing evidence-based approaches, with decisions on using preventive, diagnostic and therapeutic measures taken based on the available evidence of their effectiveness and safety on the background of search, comparison, generalization and distribution for the benefit of patients [31]. And occupational medicine, the evidence principle thereof is to cover all the aspects in scientific and clinical process: prevention, diagnosis, treatment and rehabilitation, is not an exception [1].

In scientific terms, protection of employed population health is based on the evidence of causal links between occupational factors and onset of illness (or fatality). After all, in order to prevent occupational factors

(C) Maksimov S.A., Artamonova G.V., 2016

Sergey A. Maksimov - PhD in Medical Science, associate professor; Leading Researcher of the Laboratory of Epidemiology of cardiovascular diseases (e-mail: m1979sa@ yandex.ru; tel.: +7 (384)2 64-42-40).

Galina V. Artamonova - Doctor of Medical Science, Professor, Deputy Director for Scientific Affairs, Head of the Department of optimization of medical technologies in cardiovascular diseases (e-mail: artamonova@kemcardio.ru; tel.: +7 (384) 264-45-73). 
impact, you must first prove that, namely, the occupational exposure is the direct cause (or one of the main reasons) for the disease development. At the same time, establishing causeand-effect relationships in occupational medicine is accompanied with certain difficulties. The standard clinical studies, a double blind randomized controlled parallel groups study in a large number of patients, cannot be applied in many cases in occupational medicine [1]. The principles of the evidence-based medicine therefore are necessary to be supported by the available means in the course of cohort and intervention studies.

For the diseases of multifactorial etiology, eliminating the modifying effect of the traditional (non-occupational) risk factors is a prerequisite for the evidence of cause-and-effect relationships. Considering professional occupation as a specific group of people living under the effects of certain production factors, the cause-and-effect relationship analysis should take into account, inter alia, dynamics of trends in employees' health. As part of the present review, this applies primarily to eventual inconsistency of the original (that is, at start of the employment) health status, as well as to differences in the health status of the retiring employees in test and reference groups. The first one is designated in scientific literature as healthy worker effect (HWE), the second one - as healthy worker survivor effect (HWE who continues labor activity). Both phenomena are generalized with the term "Healthy Worker Effect" (HWE).

Schematically, the prevalence of the disease under study in the occupational group is the effect of the working environment hygienic parameters, traditional risk factors and HWE [12] on health status:

1. Working environment has a direct impact on the risk of disease development (i.e., the same cause-and-effect relationship that needs to be found);

2. Working environment, under otherwise equal conditions, determine the prevalence of traditional risk factors for the disease;

3. Working environment determines workers functional level and physical health required for successful labor activity, resulting in HWE evidence;

4. Evidence of HWE by differences in the occupational groups' health status determines the prevalence of a disease and the traditional risk factors thereof;

5. Prevalence of traditional factors has a direct effect on the risk of developing the disease.

Casual relationship of the occupational effect on health is characterized by the first coherence. The last two - are the modifying effect, distorting this causal relationship and requiring to be excluded, that ensures compliance with the principles of evidencebased medicine at occupational risks assessment. A correct study management, adequate choice of groups - test and reference, using the updated means of mathematical statistics in epidemiological studies allows for identification and "neutralization" of the main factors that can modify causal relationship between the occupational exposure and the disease development.

The purpose of the present review is to consider the factors that modify cause-andeffect relationships between occupational exposures and pathology of the cardiovascular system of the employed people in epidemiological studies.

Traditional factors of cardiovascular risk.

To date, it is clear that cardiovascular disease (CVD) prevalence depends mainly on preventable causes, primarily associated with lifestyle, preventive effect thereof may slow down cardiovascular disease progression, both before and after onset of clinical symptoms. First of all, it refers to 7 risk factors, being key contributors to premature cardiovascular mortality: arterial hypertension (35.5\%), hypercholesterolemia (23\%), smoking $(17.1 \%)$, insufficient intake of fruit and vegetables (12 9\%), overweight $(12.5 \%)$, excessive alcohol consumption (11.9\%), hypodynamia (9\%) [17]. INTERHEART study demonstrated that 9 risk factors (the above-mentioned 7 plus diabetes and stress) explain $90 \%$ of the populationattributable risk of myocardial infarction [28]. 
However, consideration of the modifying effect of the traditional CVD risk factors should be started with an age, as one of the most important biological factors of cardiovascular risk. It should be borne in mind that aging is accompanied with an increasing prevalence of a number of critical risk factors: hypertension, diabetes, overweight, hypercholesterolemia, decreased physical activity [12].

The logical is the dependence of the employees' age structure on the occupational characteristics. The process of natural aging is accompanied with a decrease in adaptive capacity, morphological and functional changes in major body's systems, that leads to cumulating decrease in general and occupational ability to work, mental and physical performance [26]. It causes limitations to perform certain occupational duties, or a significant increase in physiological cost of the work performed, and accordingly to disruption of adaptabilities and development of pathological conditions [29]. As a result, in the professions related to the need for rapid response, high coordination of movements, performing higher physical activities, the proportion of people in older age groups is lower. [12] At the same time, high employment rate of older people is recorded in the professions more appropriate to their reduced functionality [21].

In this connection, comparing occupational groups of different age structure will necessarily lead to "bias" in the obtained results towards increasing prevalence of cardiovascular disease, and, in addition, towards a number of risk factors in the "older" occupational group. For example, it is revealed that shift in hypertension prevalence is accompanied with unidirectional change in the age structure and obesity prevalence in the occupational groups [14]. In particular, in occupations with a high incidence of hypertension, the employees' average age reached $43.0 \pm 2.1$ years old, while the share of persons older than 50 years: $28 \%$, the share of people with obese: $20 \%$. Occupations with low incidence of hypertension were characterized by the significantly lower average age: $39.6 \pm 1.2$ years, proportion of individuals older than 50 years: 14\%, prevalence of obesity: $15 \%$.

Therefore, along with age, other risk factors require consideration and, if possible, elimination of the modifying effect on causal relationships between the exposure to occupational factors and CVD. Moreover, a significant number of studies have shown the dependence of different risk factors prevalence on the occupational features: obesity [39], hypercholesterolemia [38], smoking [36], alcohol abuse [23] and others.

Meanwhile, the lack of analysis in the modifying effect of traditional risk factors (especially the age) on associations between the exposure to occupational factors and CVD in Russian studies is very common $[3-6,16]$.

For example, in the study [10], based on the obtained results, the authors confirm the relationship between occupation of driver with the risk factors prevalence and coronary heart disease. The data do show an increased prevalence of risk factors and coronary heart disease in drivers. However, it is not clear, if the occupational factors directly potentiate development of coronary artery disease, or, perhaps, it is the working environment that causes increase in the prevalence of risk factors, and the latter have influence on CVD prevalence respectively? The answer to this question determines possibility of considering coronary artery disease, as an occupational or occupational-mediated disease, that ultimately reflects the need, as well as the direction and scope of preventing the adverse effects of working environment.

In the study [22], one of the evidence of the occupational factors effect on the development of cardiophyshoneurosis in gasprocessing industry was a higher actual prevalence of the disease among women having "... a smaller range of adaptive capabilities to adverse environmental conditions ..." However, the authors did not pay attention to the fact that the disease in question is also recorded more frequently in women population in general, which is a feature of the gender prevalence of neuro-dystonia. 
The authors in the given study did not get the link between a higher disease prevalence and period of employment that they explained by stable hygienic situation at the enterprise. Despite it is quite possible, after all, first it is necessary to proceed from the fact that cardiopsychoneurosis is often diagnosed in young and middle age, that is, in workers with short period of employment. Thereby, the consistencies, the authors got, do not reflect occupational dependence of the diseases, but merely the associative links (age - period of employment, age - disease, period of employment disease), which are not always cause-andeffect.

The CVD dependence on occupational factors is often confirmed by the existing correlations between disease prevalence and employment period. At the same time, it may often be a serious methodological error $[2-6,16$, 22]. In most cases, period of employment is closely (a direct strong correlation) associated with employees' age. And when you consider that probability of CVD development in major cases and risk factors is also closely linked to age (also a direct strong correlation), then onefactor correlations of an employment period with CVD and risk factors are typically not cause-and-effect, but rather associative, i.e., mediated by age.

Eliminating the modifying effect of CVD traditional risk factors is optimally achieved by forming such occupational groups for study, in which the differences by the given risk factors are minimized. In case it's impossible, and it happens often enough, the modifying effect of traditional risk factors is excluded at the stage of data analysis using statistical methods of processing.

For example, in studying 13 occupational groups of men, direct standardization [13] was used for this purpose. Eliminating the effect of age and obesity led to changes in the initial values of occupational risks of hypertension by an average of $10 \%$, and the level of statistical significance of disease risks in four occupational groups changed. It was found that high prevalence of hypertension among managers, maintenance and technical personnel and, on the other hand, low disease prevalence among the subsurface equipment operators and heavy unskilled labor staff is not connected with the working conditions, but with high/low share of persons with obesity and of aging workers in these occupational groups.

In foreign studies, a common methodological technique to eliminate the modifying factors impact is the use of multivariate linear or logistic regression analysis. At the first stage a single-factor relationship of a disease with occupational factor is considered, at the second: risk factors as independent predictors are added to the regression analysis. In this case, if the relationship between disease prevalence and occupational factors remains statistically significant, it is only in this case, causal link is ascertained. A similar sequence of actions is at using partial correlations.

Healthy worker effect. Currently HWE is regarded as an organized and / or disorganized occupational selection of healthier workers in poor working conditions, which leads to better health parameters, compared with those employed with more favorable labor conditions or with the population in general. As a result, actual increase in morbidity/mortality as occupational factors effect may be wholly or partially "masked" $[11,34]$.

HWE could be a consequence of two reasons. First, individuals with poor health are excluded from professional activity, since pathological or functional abnormalities can be theoretically or actually an obstacle to adequate execution of professional duties. Secondly, executing professional duties by healthy person or on the back of existing pathological or functional abnormalities leads to (or can cause) health deterioration.

On the other hand, health deterioration in occupational cohort, as compared with the reference group, is always treated as a result of occupational exposure. Such studies do not consider the eventual HWE-reverse phenomenon. Meanwhile, if individuals with impaired health are excluded from some professional cohorts, they will add another occupational 
cohort that increases the diseases prevalence therein [12].

The HWE phenomenon conditionally allocates two components: healthy hire effect (HHE, Eng: healthy hire effect) and healthy worker effect to continue labor activity (HWSE, Eng: healthy worker survivor effect) [11].

HHE characterizes HWE in a starting period of employees' professional activity, due to the fact that healthier individuals apply to work in adverse working conditions or to an employment at all, compared to individuals with poorer health status or with reduced functionality. HHE identification is not difficult. Hypothetically, among young adults, job seekers, a health should not be fundamentally different from the general population, and the working conditions effect on health should occur only after a certain period of exposure (time of employment). Therefore, the best indicators of health status among young adults with a minimum length of employment, compared with the general population or other professional cohort, indicates HHE.

HWSE refers to the ongoing process of occupational selection and is characterized by the fact that individuals who continue working are healthier than those who leave professional activity. For example, it is shown that retiring workers in agriculture have worse health in terms of CVD compared with those who continue labor activity [20].

HWE at CVD is clearly seen at an early working age [30]. The Croatian study of hypertension prevalence on the example of six occupational groups is indicative in this respect [37]. The study results did not confirm the existence of positive relationship between potentially hazardous working conditions in professional occupations considered $\mathrm{s}$ and development of the disease. The minimum prevalence of hypertension was observed in the workers of transportation, characterized by heavy physical labor, the maximum prevalence of the disease - in the warehouse staff. However, the authors noted that the occupational cohort of warehouse workers is made up largely from the transport workers, being trans- ferred, due to age, illness or reduced performance, to a lighter work.

Another study [15] showed lower, compared to the all-Russia data and the other occupational groups, prevalence of hypertension in underground miners (including the youngest), exposed to a number of unfavorable factors of production. In this case, HWE should be seen as a consequence of the legislated selection of healthy individuals for employment in underground conditions (Order of the Health Ministry of Russia ddt. April 12, 2011 No. 302n "On approval of lists of harmful and (or) hazardous production factors and works, subject to compulsory preliminary and periodic medical examinations (surveys) and the Order of mandatory preliminary and periodic medical examinations (surveys) of individuals employed in heavy work or work in harmful and (or) dangerous working conditions").

Unfortunately, similar studies considering the causes of cardiovascular disease prevalence in occupational groups are sporadic. The vast majority of studies merely state the fact of an increased or decreased prevalence of the disease, which is interpreted as presence/absence of CVD occupational dependence [18]. Several studies also testify certain illogicality in reducing CVD prevalence in occupational groups, characterized by unfavorable working conditions and increase in the prevalence of cardiovascular disease in relatively favorable occupations [24, 27].

The studies [2, 8-9, 19] observe an increase in the prevalence of cardiovascular disease in occupational groups of vehicles drivers, which is associated with psycho-emotional effect of work, with a decrease in motor activity that represents both independent and indirect (through an increase in body mass index) risk factor. The eventual effect of these factors causes no doubt, but that does not reduce probable "accumulation" of persons with cardiovascular disease in a cohort of professional drivers. Three of these studies [2, 8-9] involved age-specific analysis of the cardiovascular disease prevalence that showed, as a rule, high prevalence of the disease in all age groups, including the youngest. As noted 
above, hypothetically young drivers health status should not be fundamentally different from the general population, and working conditions impact and reduced motor activity against health status should become evident only after a certain period of exposure (time). Therefore, high prevalence of CVD among young drivers indicates most likely an initially worse state of health.

It is indicative in the given aspect a comparative analysis of anthropometric, biochemical parameters and pressure levels of young (21-24 years old) London conductors and drivers [33]. The higher weight, fat content, lipid concentrations and the elevated blood pressure levels are observed in drivers already in young age. According to the authors, it characterizes not the occupational exposure, but the profiles of occupational selection.

Nowadays, in order to reduce /eliminate HWE, the approaches developed at the end of the $\mathrm{XX}$ century are used. Much attention in reducing the influence of $\mathrm{HWE}$ on causal relationship between occupational exposure and health parameters is given to careful planning and selection of reference groups. At the same time, it is recommended not to use general population as reference, but workers of the other occupations with the absence of the risk factors under study or workers of the same occupation, differing only in the degree of exposure to these risk factors.

One of the most effective control areas in HWE is recognized the occupational cohort analysis of health parameters, taking into account those who left the given cohort. At the same time, workers, who leave their professional occupation, exhibit increased mortality or morbidity, which is one of the evidences of HWSE.

Since the late 1970s, in order to reduce HWE, the standard analytical methods of data processing are in use: relative and standardized risks [25, 35], stratification analysis, taking into account age and gender as modifying factors [35], employment status [25], logging an exposure [25, 34-35], structural modeling [32]. However, it is clear to date, that a common method allowing for HWE elimination have failed to get developed, so the current trend is a comprehensive approach to assessing HWE existence and possibilities to exclude it in each particular study [11].

We have developed methodological approaches that allow by epidemiological data to identify and correct HWE modifying effect on a relative risk and etiologic share of the disease in occupational groups. In this case, identification and correction of two main influencing components in HWE (HHE and HWSE) are different. Epidemiological study of transversal design identifies and eliminates the potential modifying effect of HWE only. Identification and elimination of HWSE can only be possible, if data on health status of people who left profession are available for a certain period of time. In addition, the similar data on the reference group are necessary.

To identify HHE, we did age-specific and employment time-related analysis of health deteriorations prevalence in the workers. In this case, it is assumed that the differences in health deteriorations prevalence in the minimum age/employment time groups of the compared professional employment timerelated cohorts would indicate the presence of HHE.

When you select grouping by age or length of employment period, it should be borne in mind that both the one and the other have their own advantages and disadvantages. One of the basic axioms of HHE identification method developed is the assumption that working conditions impact on health should appear only after a certain period of exposure (time). However, the length of the worker's professional employment period is difficult to control due to individual features of eventual occupational route. For example, a man may be employed directly by the profession considered, since reached his working age, can go into it later in life from a similar profession or from a completely different profession. Finally, a man can start his labor activity not since his working age is achieved, but after a while.

In contrast to the employment timeperiod, an employee's age is an easily controlled indication, which is, moreover, strongly 
correlated with the employment time-period. Usually, grouping by age in general provides adequate grouping of workers by professional occupation period, that is, a young-age group includes mostly employees with a minimum occupation period. Furthermore, when all the population is used as reference group, it is not always possible to consider professional employment period, in many cases such data are simply absent.

To reveal HHE, it's greatly important to identify certain age/employment period the diseases developed wherein are recognized as not associated with occupational exposure. Due to the fact that in many cases time-period relationship of the disease in question with occupational factors effect is not established, a minimum age/employment period is accepted as: age under 25 years old, under 30 years old, or employment period of up to 5 years, up to 10 years.

It should be noted that the proposed algorithm for HHE identification is applicable not for all health disorders. Several CVD cases develop mainly in older age, such as coronary heart disease. Therefore, the disease prevalence in the analysis of minimum age or employment-period groups will show nothing. For example, under 30 years old, CHD is recorded in individual cases, in view of this, lack of differences in the disease prevalence in the given age group prevents from stating HHE absence. In this case it's useful to analyze the indices of predisposition to cardiovascular disease, in particular, the risk factors.

HHE on the incidence of cardiovascular disease is excluded by correcting the benchmark data for the disease prevalence in a minimum age or employment period group. A correction algorithm includes a series of successive analytical transforming the benchmark data of the test group by standardization type. The correction is based on the assumption that an incidence of HHE should manifest itself equally in all age groups. That is, a relative risk of CVD in young workers of the test and reference groups should not change with increasing age, and any deviations will not be HHE-associated. According to the corrected absolute values of the number of patients, we can calculate the disease prevalence, as well as the relative risk value without HHE.

As noted above, identification and elimination of HWSE is possible provided the available data on the health status of persons retired from the test and reference occupations for a certain period of time. Significant differences in the proportion of patients among the resigning in these groups may indicate HWSE. It should be noted that, when identifying HWSE, data on the health status of retiring workers should be taken into account for the same period of time for the test and reference groups. What time period will be taken into account: 1 year, 2 years, 3 years, 5 years does not matter. It is only necessary to bear in mind that this time period will characterize HWSE calculated.

At the first stage we calculate the proportion of the retired sick workers from the total number of the test and reference groups, and the difference between them. The differences intensity characterizes the intensity of HWSE. The identified HWSE incidence towards CVD prevalence and risk is eliminated by standardized correcting the number of workers with pathology in the test group for the difference of the retired with CVD in the test and reference groups.

Approbation of our methodological approaches on the example of hypertension in 13 occupational groups of men gave positive results [7]. In the course of successive correcting and eliminating HHE and HWSE incidence, in a number of occupational groups we obtained values of risks significantly different from the benchmarks. The variations in hypertension risk values at correction for HHE ranged from $6 \%$ to $76 \%$ (37\% in average), for HWSE from $0 \%$ to $11 \%$ (5\% in average).

Conclusion. Thus, the published data show stronger role of the modifying impact of traditional risk factors and HWE in forming the levels of CVD in the employed population. This modifying effect is necessary to be identified and excluded when analyzing causal relationships between occupational exposure and CVD development. A wider and more exten- 
sive use of the actually developed methodological approaches to the formation of test samplings, of analytical and statistical results pro- cessing techniques allow for significant increase in adequacy and reliability of the national epidemiological studies.

\section{References}

1. Amirov N.H., Fathutdinova L.M. Dokazatel'naja medicina kak osnovopolagajushhij princip organizacii ohrany zdorov'ja rabotnikov [Evidence-based medicine as a fundamental principle of health care management for workers]. Medicina truda i promyshlennaja jekologija, 2011, no. 9, pp. 1-4 (in Russian).

2. Popov A.I., Salamatina L.V., Prokopenko L.V., Buganov A.A. Arterial'naja gipertenzija i faktory riska u voditelej avtotransporta na Krajnem Severe [Arterial hypertension and risk factors in automobile drivers of Far North]. Medicina truda i promyshlennaja jekologija, 2007, no. 1, pp. 16-22 (in Russian).

3. Afanasova O.E., Poterjaeva E.L., Vereshhagina G.N. Vlijanie uslovij truda na formirovanie arterial'noj gipertenzii u rabotajushhih $\mathrm{v}$ uslovijah vysokogo professional'nogo riska [Influence of work conditions on arterial hypertension formation in workers under high occupational risk]. Medicina truda $i$ promyshlennaja jekologija, 2010, no. 8, pp. 19-22 (in Russian).

4. Kopejkin N.F., Stankevich A.I., Bondareva A.R., Boeva I.A. Gipertonicheskaja bolezn' kak profzabolevanie rabotnikov lokomotivnyh brigad [Essential hypertension as an occupational disease in engine crew members]. Gigiena $i$ sanitarija, 2011, no. 3, pp. 28-30 (in Russian).

5. Ereniev S.I., Zahar'eva S.V. Faktory riska razvitija serdechno-sosudistyh zabolevanij u rabotnikov osnovnyh professij mashinostroitel'nogo predprijatija [Cardiovascular risk factors in the main professional groups in a machinebuilding plant]. Klinicheskaja medicina, 2006, no. 8, pp. 31-34 (in Russian).

6. Zaharenkov V.V., Omarova D.K. Sostojanie kardiorespiratornoj sistemy rabotnikov sovremennogo tantalovogo proizvodstva [Cardiorespiratory status in contemporary tantalum production workers]. Medicina truda i promyshlennaja jekologija, 2012, no. 3, pp. 19-25 (in Russian).

7. Maksimov S.A., Skripchenko A.E., Mihajluc A.P., Artamonova G.V. Identifikacija professional'nogo riska arterial'noj gipertenzii. Soobshhenie II: ustranenie jeffekta zdorovogo rabochego [Identification of occupational risk for arterial hypertension. Report II: elimination of the modifyng influence of factors of cardiovascular risk]. Gigiena $i$ sanitarija, 2016, no. 4, pp. 365-369 (in Russian).

8. Kalmykova M.A., Jel'garov M.A. Osobennosti jepidemiologii narushenij ritma serdca u voditelej avtotransporta [Epidemiologic features of heart arrhythmias in automobile drivers]. Medicina truda $i$ promyshlennaja jekologija, 2010, no. 11, pp. 23-27 (in Russian).

9. Kerefova Z.Sh., Zhilova I.I., Jel'garov A.A. Vlijanie proizvodstvennyh uslovij na chastotu ishemicheskoj bolezni serdca u voditelej avtotransporta [Influence of occupational environment on coronary heart disease incidence in automobile transport drivers]. Medicina truda i promyshlennaja jekologija, 2007, no. 5, pp. 18-23 (in Russian).

10. Kerefova Z.Sh., Zhilova I.I., Jel'garov A.A. Ishemicheskaja bolezn' serdca u voditelej avtotransporta (chastota, professional'naja rabotosposobnost') [Coronary heart disease in drivers: prevalence and professional work capacity]. Kardiovaskuljarnaja terapija i profilaktika, 2007, no. 7, pp. 25-30 (in Russian).

11. Maksimov S.A. Jeffekt zdorovogo rabochego $\mathrm{v}$ jepidemiologicheskih issledovanijah [Healthy worker effect in epidemiological researches]. Medicina v Kuzbasse, 2015, no. 2, pp. 10-16 (in Russian).

12. Maksimov S.A., Artamonova G.V. Professija i arterial'naja gipertenzija [Occupation and hypertension]. Kemerovo, Firma POLIGRAF Publ., 2015, 156 p. (in Russian).

13. Maksimov S.A., Mihajluc A.P., Artamonova G.V. Identifikacija professional'nogo riska arterial'noj gipertenzii. Soobshhenie I: ustranenie modificirujushhego vlijanija faktorov serdechno-sosudistogo riska [Identification of occupational risk for arterial hypertension. 1: elimination of the modifyng influence of factors of cardiovascular risk]. Gigiena i sanitarija, 2016, no. 3, pp. 262-266 (in Russian).

14. Maksimov S.A., Skripchenko A.E., Artamonova G.V. Professional'nyj otbor i rasprostranennost' arterial'noj gipertenzii sredi rabotajushhego naselenija Zapadnoj Sibiri [Occupational selection and prev- 
alence of arterial hypertension in working population of Western Siberia]. Medicina v Kuzbasse, 2013, no. 4, pp. 41-47 (in Russian).

15. Maksimov S.A., Skripchenko A.E., Artamonova G.V. Riski razvitija arterial'noj gipertenzii v professional'nyh gruppah Zapadnoj Sibiri: sravnenie s nacional'nymi dannymi [Risks of development of arterial hypertension in occupational groups of Western Siberia: comparison with national representative data]. Vestnik RAMN, 2012, no. 12, pp. 54-59 (in Russian).

16. Cimakuridze M.P., Kverenchhiladze R.G., Bakradze L.Sh., Hachapuridze N.A., Kurashvili B.V. Nekotorye pokazateli sostojanija zdorov'ja rabochih gorjachih professij [Some health indicators Workers hot jobs]. Allergologija i immunologija, 2010, no. 2, pp. 132-134 (in Russian).

17. Oganov R.G., Maslennikova G.Ja. Jepidemiju serdechno-sosudistyh zabolevanij mozhno ostanovit' usileniem profilaktiki [The epidemics of cardiovascular diseases can be stopped by strengthening their prevention]. Profilakticheskaja medicina, 2009, no. 6, pp. 3-7 (in Russian).

18. Kalinina A.M., Koncevaja A.V., Belonosova S.V., Eganjan R.A., Pozdnjakov Ju.M., Kiseleva N.V. Realizacija programmnogo cikla profilaktiki serdechno-sosudistyh zabolevanij na rabochem meste: klinicheskaja jeffektivnost' [Workplace programme of cardiovascular prevention: clinical effectiveness]. Kardiovaskuljarnaja terapija i profilaktika, 2010, no. 3, pp. 90-97 (in Russian).

19. Sibekova T.V., Jel'garov A.A., Jel'garov M.A. Serdechno-sosudistye zabolevanija u rabotajushhih zhenshhin i puti profilaktiki [Cardiovascular diseases in female workers and methods of their prevention]. Medicina truda i promyshlennaja jekologija, 2007, no. 5, pp. 13-18 (in Russian).

20. Trubeckov A.D., Migacheva A.G., Starshov A.M. Sostojanie zdorov'ja uvolivshihsja rabotnic teplichnyh hozjajstv [Health condition of drop out greenhouses workers]. Mezhdunarodnyj zhurnal prikladnyh i fundamental'nyh issledovanij, 2016, no. 4-2, pp. 383-385 (in Russian).

21. Cherkasskaja E.A. Professional'no-demograficheskij analiz zanjatosti naselenija SSSR, RSFSR i USSR po dannym vsesojuznyh perepisej [Professionally - demographic analysis of the employment population of the USSR, the RSFSR and the Ukrainian SSR according to the All-Union census]. Gigiena truda i professional'nye zabolevanija, 1991, no. 5, pp. 4-6 (in Russian).

22. Shevchenko M.I., Davydova L.D. Zabolevanija serdechno-sosudistoj sistemy u rabochih gazopererabatyvajushhego zavoda [Cardiovascular diseases in workers of gas-processing plant]. Medicina truda i promyshlennaja jekologija, 2005, no. 1, pp. 32-35 (in Russian).

23. Mandell W., Eaton W.W., Anthony J.C., Garrison R. Alcoholism and occupations: a review and analysis of 104 occupations. Alcoholism Clinical and Experimental Research, 1992, vol. 16, pp. 734746.

24. Applebaum K.M., Malloy E.J., Eisen E.A. Reducing healthy worker survivor bias by restricting date of hire in a cohort study of Vermont granite workers. Occupational and Environmental Medicine, 2007 , vol. 64, pp. 681-687.

25. Arrighi H.M., Hertz-Picciotto I. The evolving concept of the healthy worker survivor effect. Epidemiology, 1994, vol. 5, pp. 189-196.

26. Costa G., Sartori S. Ageing, working hours and work ability. Ergonomics, 2007, vol. 50, pp. 1914-1930.

27. Wada K., Katoh N., Aratake Y., Furukawa Y., Hayashi T., Satoh E., Tanaka K., Satoh T., Aizawa Y. Effect of overtime work on blood pressure and body mass index in Japanese male workers. Occupational Medicine (London), 2006, vol. 56, pp. 578-580.

28. Yusuf S., Hawken S., Ounpuu S., Dans T., Avezum A., Lanas F., McQueen M., Budaj A., Pais P., Varigos J., Lisheng L. Effect of potentially modifiable risk factors associated with myocardial infarction in 52 countries

(the INTERHEART study): case-control study. Lancet, 2004, vol. 364, pp. 937-952.

29. Schapkin S.A., Freude G., Gajewski P.D., Wild-Wall N., Falkenstein M. Effects of working memory load on performance and cardiovascular activity in younger and older workers. International Journal of Behavioral Medicine, 2012, vol. 19, pp. 359-371.

30. Enterline P.E. Comments on the "healthy worker effect" in occupational epidemiology. In: Reports to the Workers' Compensation Board on the Healthy Worker Effect. Toronto, Canada: Ministry of Labour of 
the Government of Ontario, ISDP Report No 3. 1988. Available at: http: //www.canoshweb.org/odp/html/JUL1988.htm (19.09.2016).

31. Evidence-based health care: a new approach to teaching the practice of health care. EvidenceBased Medicine Working Group. Journal of Dental Education, 1994, vol. 58, pp. 648-653.

32. Dumas O., Le Moual N., Siroux V., Heederik D., Kauffmann F., Basagana X. Marginal structural models to quantify and control for the healthy worker effect in asthma: results from the EGEA study. Respiratory and Critical Care Medicine, 2012, vol. 185, pp. A1175.

33. Oliver R.M. Physique and serum lipids of young London busmen in relation to ischaemic heart disease. British Journal of Industrial Medicine, 1967, vol. 24, pp. 181-186.

34. Pearce N., Checkoway H., Kriebel D. Bias in occupational epidemiology studies. Occupational and Environmental Medicine, 2007, vol. 64, pp. 562-568.

35. Thygesen L.C., Hvidtfeldt U.A., Mikkelsen S., Bronnum-Hansen H. Quantification of the healthy worker effect: a nationwide cohort study among electricians in Denmark. BMC Public Health, 2011, vol. 11, pp. 571.

36. Kouvonen A., Vahtera J., Väänänen A., De Vogli R., Heponiemi T., Elovainio M., Virtanen M., Oksanen T., Cox S.J., Pentti J., Kivimäki M. Relationship between job strain and smoking cessation: the Finnish Public Sector Study. Tobacco Control, 2009, vol. 18, pp. 108-114.

37. Skrobonja A., Kontosic I. Arterial hypertension in correlation with age and body mass index in some occupational groups in the harbour of Rijeka, Croatia. Industrial Health, 1998, vol. 36, pp. 312317.

38. Thomas C., Power C. Do early life exposures explain association in mid-adulthood between workplace factors and risk factors for cardiovascular disease? International Journal of Epidemiology, 2010, vol. 39, pp. 812-824.

39. Church T.S., Thomas D.M., Tudor-Locke C., Katzmarzyk P.T., Earnest C.P., Rodarte R.Q., Martin C.K., Blair S.N., Bouchard C. Trends over 5 decades in U.S. occupation-related physical activity and their association with obesity. PLoS One, 2011, vol. 6, e19657.

Maksimov S.A., Artamonova G.V. Occupation and pathology of the cardiovascular system: factors that modify the causal relations in epidemiological studies. Health Risk Analysis, 2016, no. 4, pp. 88-97. DOI: 10.21668/health.risk/2016.4.11.eng

Received: 13.09.2016

Accepted: 16.12.2016

Published: 30.12.2016 